\title{
Anti-icing Capacity and Service Life Research on the Controlled Released Anti-icing Asphalt Modifier
}

\author{
Miaomiao Tian ${ }^{1, a}$, Baolin Zhu ${ }^{1}$, Yanhua Cao ${ }^{1}$, Ruinan Jiang ${ }^{1}$, Shixiang Yan $^{2}$ \\ ${ }^{1}$ China Academy of Transportation Sciences 617, Huixinli 240\#, Chaoyang District, Beijing, China, 100029 \\ ${ }^{2}$ Yunnan Highway Science \& Technology Research Institution, Chuanjin Road 3\#, Panlong District, Kunming City, Yunnan Province, China
}

\begin{abstract}
The release rate of chloride ions could be controlled by adding additives into the anti-icing modifier, for the purpose of extending the modifier's usage life. The anti-icing capacity of the modifier with controlled released additives was researched in this paper by the "Chloride ion concentration change monitoring test" and "Dynamic water simulation test", and the service life of the modifier has been analyzed.
\end{abstract}

\section{Introduction}

Road icing is regarded as one of the most dangerous factors of causing traffic accidents in winter. Therefore, to discover an efficient, economic and environmentally friendly anti-icing way to guarantee safety driving on roads has become a hot-button issue to the road managers ${ }^{1}$. Nowadays, commonly used methods are spreading snow melting additives, manpower ice removal, etc., which seems to be inefficiency, and harmful to the environment once the excess salt permeates the surrounding soil ${ }^{2}$. Adding anti-icing modifiers into the asphalt mixture has been known as an effective approach. However, as the salt based components would be rapidly separated out when it meets water, the durability of the modifier is sometimes unsatisfied and the usage life is often shorter than what it has been originally designed ${ }^{6}$.

To prevent the modifier's excessive dissolution in water condition in rainy summer seasons, and ensure its working performance in winter, a new kind of anti-icing modifier with controlled released additives has been independently researched and developed in this paper. Its validity has been firstly evaluated based on capacity tests, and the service life has also been predicted at last.

\section{Determination of the modifier's optimum adding amount}

The anti-icing modifier plays a key role to the freezethaw splitting strength of the asphalt mixture. The freeze-thaw splitting strength of asphalt mixture was verified by the addition of different anticoagulant ice modifiers, for determining of the modifier's optimum adding amount.

It is can be seen from figure 1, with the addition of the anti-icing modifier, the strength of the AC-13 has gradually increased after the freeze-thaw cycles. The possible reason is that at the temperature of $-18^{\circ} \mathrm{C}$, the anti-icing modifier has a reaction with asphalt and then its strength increased and become a permanent strength. When freezing and thawing finished, the anti-icing modifier has played a role during both the splitting process and insulation at the water of $25^{\circ} \mathrm{C}$, which led to a result that the strength of the mixture after adding the modifier was higher than those without the modifier. The more amount of the anti-icing modifier was added, the trend was more obviously to see.

With addition of the anti-icing modifier, freeze-thaw splitting strength ratio increased first and then decreased. When the adding amount of the modifier was $5 \%$ of the asphalt mixture, the freeze-thaw splitting strength has reached the peak value. Freeze-thaw splitting strength ratio was mainly affected by the strength of after and before the freeze-thaw procedure. The modifier gave a significant influence to the splitting strength after freezing and thawing, thus the ratio was changing along with the adding amount of the modifier. According to the 
research, it can be seen that the optimum adding amount of the modifier in the asphalt mixture was suitable for $5 \%$

\section{Anti-icing Capacity Research}

Apply the "Rapid Determination of Chloride Ion Content Instrument" to assess the release rate of the chloride ion. Via the tests of "Chloride ion concentration change monitoring" and "Dynamic water simulation", the capacity of the anti-icing asphalt modifier with the controlled released additives has been analyzed.

\subsection{Chloride ion concentration change monitoring test}

\subsubsection{Test method}

Marshall Specimens named A and B were prepared and totally soaked in water at the room temperature for $24 \mathrm{~h} / \mathrm{d}$, continuously lasted for 20 days. Test the chloride ion concentration daily. The durability of the modifier could be evaluated by determining the change of chloride ion in solution. The tests results are shown in table 5 and figure 2 .

\subsubsection{Test results analysis}

The ratio of the modifier was $5 \%$ of the asphalt mixture. Each Marshall Specimen was regarded as 1200g; the mass of the modifier was $60 \mathrm{~g} / \mathrm{specimen}$. The molar mass of salt based chemical composition in the modifier was considered to be $33.8 \mathrm{~g} / \mathrm{mol} / \mathrm{specimen}$. After soaked for 20 days, the total amount of chloride ion separated out was $0.286 \mathrm{~mol} / \mathrm{L}$, the loss mass was $10.15 \mathrm{~g} / \mathrm{L}$, and the residual amount of the modifier was $49.98 \mathrm{~g}$. Therefore, in case of the worse immersion conditions on pavements, there was still enough residual modifier in the mixture, which can keep the capacity of anti-icing. The effect of controlling release has been achieved.

It is can be seen from the figure 2, with the separating out and dissolution of the chloride ion, the final concentration in water has reached a peak then become stable lines. It seems that the chloride ion which can be soaked and dissolved by water has totally been separated out. Considering the realities on roads, after continuous immersion, traffic loads was supposed to be the main reason that caused the residual chloride ion precipitation, to against the road icing year by year.

Thus, the chloride ion can be controllably released and the modifier's working performance can be trusted in winter. The durability of the modifier was satisfied.

\subsection{Dynamic water simulation test}

\subsubsection{Test method}

Make three anti-icing asphalt mixture specimens, soaked them into the water at temperature of $-10^{\circ} \mathrm{C}, 0{ }^{\circ} \mathrm{C}$, $5^{\circ} \mathrm{C}, 15^{\circ} \mathrm{C}, 25^{\circ} \mathrm{C}, 35^{\circ} \mathrm{C}$, respectively. According to the average annual rainfall of $72 \mathrm{~L}$ in the test area, spray water to the specimens in 10 times until it has reached the total amount of the average annual rainfall. Under the condition of simulated hot and rainy summer season, test the chloride content of the collecting water after every time shower to determine the loss amount of the chloride ion in each specimen. The test results are shown in Table 6 and Table 7.

\subsubsection{Test results analysis}

The adding amount of the modifier with the controlled release additives was $5 \%$ of the mixture. As the weight of the every rutting specimen was $10500 \mathrm{~g}$, the mass of the modifier was $525 \mathrm{~g}$ for each. After shower for 10 times, the residual amount of the modifier can be calculated by the loss amount of the chloride ion tested in the collecting water shown in Table 6 . The molar mass was considered to be $33.8 \mathrm{~g} / \mathrm{mol}$ of the modifier for each specimen.

It is can be seen form Table 6, after 10 times shower onto the three rutting specimens at each temperature above, the test result showed that the amount of the chloride ion in the collecting solution was gradually increased after each time shower. It impacted that in the situation of wet pavement, there was partial loss of the chloride ion of the modifier. However, it also can be seen from the calculation in table 7 that, after a year of concentrated rainfall, there was still anti-icing modifier existed in the rutting test specimen. It indicated that under the function of the controlled release addictive, the average annual rainfall would neither wash away the whole efficient part of the modifier, nor cause a decisive influence to decrease its anti-icing working capacity in winter.

Figure 3 has shown that, there was no obvious difference of the chloride ion precipitation when it was tested at a high or low temperature. As the modifier was wrapped by asphalt, with the combination effect of the controlled release additives, great loss of the chloride ion in the modifier has been successfully prevented. Thus, in hot rainy summer, it will not cause a large amount of dissolution of the modifier, and the anti-icing function could be guaranteed. 


\section{Service life prediction}

According to table 7 , after raining for a year, there was still a satisfied amount of modifier stayed in the specimen. According to the calculation of annual loss, the modifier was predicted to be used for approximately $14 \sim 20$ years. With the function of the controlled released additives, the durability of the modifier was approved, and the target of road safety driving in winter could be achieved.

\section{Conclusions}

(1) Deposition rate of the chloride ion could be decreased by adding the controlled released additives into the anti-icing modifier, and the excess loss could be reduced.

(2) According to the whole day immersion and the average annual rainfall water spray tests, the ice removal working performance has been analyzed. Moreover, the loss ratio of the modifier has been calculated and the usage years was predicted. The test results showed that the modifier has satisfied anti-icing capacity, and the release rate of the modifier can be controlled.

(3) With the function of the addictives, the chloride ion would not sharply deposit, therefore the modifier would sustained release for the design years. The effective service life of the modifier has been extended.

Table 1. AC-13 with $0 \%$ modifier freeze-thaw splitting strength test.

\begin{tabular}{|c|c|c|c|c|c|c|c|c|c|c|}
\hline $\begin{array}{l}\text { Adding } \\
\text { amount } \\
(\%)\end{array}$ & $\begin{array}{l}\text { Height } \\
(\mathrm{mm})\end{array}$ & $\begin{array}{c}\text { Air } \\
\text { weight } \\
(\mathrm{g})\end{array}$ & $\begin{array}{c}\text { Water } \\
\text { weight } \\
(\mathrm{g})\end{array}$ & $\begin{array}{l}\text { Dry } \\
\text { weight } \\
(\mathrm{g})\end{array}$ & $\begin{array}{c}\text { Bulk } \\
\text { density } \\
\left(\mathrm{g} / \mathrm{cm}^{3}\right)\end{array}$ & $\begin{array}{l}\text { Splitting } \\
\text { load }(\mathrm{kN})\end{array}$ & $\begin{array}{l}\text { Flow } \\
\text { value } \\
(\mathrm{mm})\end{array}$ & $\begin{array}{c}\text { Strength } \\
\text { before } \\
\text { freeze-thaw } \\
(\mathrm{MPa})\end{array}$ & $\begin{array}{l}\text { Strength } \\
\text { after freeze- } \\
\text { thaw (MPa) }\end{array}$ & $\begin{array}{l}\text { Strength } \\
\text { ratio (\%) }\end{array}$ \\
\hline \multirow{8}{*}{0} & 64.1 & 1296.9 & 796 & 1299.4 & 2.576 & 11.01 & 2.23 & / & 1.08 & \multirow{9}{*}{83.07} \\
\hline & 64 & 1291.2 & 790.1 & 1293.2 & 2.566 & 12.69 & 2.63 & 1.247 & I & \\
\hline & 63.4 & 1292.3 & 791.1 & 1293.3 & 2.573 & 11.89 & 2.61 & / & 1.168 & \\
\hline & 63.4 & 1291.2 & 788.2 & 1292.6 & 2.56 & 13.82 & 2.91 & 1.37 & l & \\
\hline & 64.4 & 1295 & 791.5 & 1297.1 & 2.561 & 10.43 & 2.36 & / & 1.018 & \\
\hline & 64.5 & 1291 & 789.8 & 1293.9 & 2.561 & 13.00 & 1.81 & 1.267 & I & \\
\hline & 64.2 & 1288.9 & 789.4 & 1290.6 & 2.572 & 12.56 & 2.05 & / & 1.23 & \\
\hline & 63.8 & 1288.5 & 788.2 & 1290.3 & 2.566 & 15.51 & 2.53 & 1.528 & / & \\
\hline Average & 64 & 1291.9 & 790.5 & 1293.8 & 2.567 & / & / & 1.353 & 1.124 & \\
\hline
\end{tabular}

Table 2. AC-13 with 2\% modifier freeze-thaw splitting strength test.

\begin{tabular}{|c|c|c|c|c|c|c|c|c|c|c|}
\hline $\begin{array}{c}\text { Adding } \\
\text { amount } \\
(\%)\end{array}$ & $\begin{array}{c}\text { Height } \\
(\mathrm{mm})\end{array}$ & $\begin{array}{c}\text { Air } \\
\text { weight } \\
(\mathrm{g})\end{array}$ & $\begin{array}{c}\text { Water } \\
\text { weight } \\
(\mathrm{g})\end{array}$ & $\begin{array}{c}\text { Dry } \\
\text { weight } \\
(\mathrm{g})\end{array}$ & $\begin{array}{c}\text { Bulk } \\
\text { density } \\
\left(\mathrm{g} / \mathrm{cm}^{3}\right)\end{array}$ & $\begin{array}{c}\text { Splitting } \\
\text { load }(\mathrm{kN})\end{array}$ & $\begin{array}{c}\text { Flow } \\
\text { value } \\
(\mathrm{mm})\end{array}$ & $\begin{array}{c}\text { Strength } \\
\text { before freeze- } \\
\text { thaw }(\mathrm{MPa})\end{array}$ & $\begin{array}{c}\text { Strength after } \\
\text { freeze-thaw } \\
(\mathrm{MPa})\end{array}$ & $\begin{array}{c}\text { Strength } \\
\text { ratio } \\
(\%)\end{array}$ \\
\hline \multirow{5}{*}{2} & 63.3 & 1289.6 & 791.4 & 1290.9 & 2.582 & 12.21 & 2.23 & 1.213 & $/$ \\
\cline { 2 - 11 } & 62.8 & 1286.1 & 791.1 & 1286.9 & 2.594 & 11.81 & 1.69 & $/$ & 1.182 \\
\cline { 2 - 11 } & 62.9 & 1285.3 & 789.4 & 1286.4 & 2.586 & 13.77 & 2.24 & 1.376 & $/$ \\
\cline { 2 - 11 } & 63.1 & 1286 & 792.2 & 1287.2 & 2.598 & 11.96 & 2.28 & $/$ & 1.192 \\
\cline { 2 - 11 } & 63.6 & 1287.3 & 788.9 & 1288.9 & 2.575 & 13.30 & 1.96 & 1.315 & $/$ \\
\cline { 2 - 10 } & 62.9 & 1283.3 & 787.6 & 1284.2 & 2.584 & 11.22 & 1.69 & $/$ & 1.121 \\
\cline { 2 - 10 } & 62.8 & 1283.6 & 789.3 & 1284.8 & 2.591 & 13.96 & 1.76 & 1.398 & $/$ \\
\cline { 2 - 10 } & 62.6 & 1283 & 787.6 & 1284.2 & 2.584 & 12.26 & 2.34 & $/$ & 1.231 \\
\hline \multirow{2}{*}{ Average } & 63 & 1285.5 & 789.7 & 1286.7 & 2.587 & $/$ & $/$ & 1.325 & 1.182 \\
\hline
\end{tabular}


Table 3. AC-13 with $4 \%$ modifier freeze-thaw splitting strength test.

\begin{tabular}{|c|c|c|c|c|c|c|c|c|c|c|}
\hline $\begin{array}{c}\text { Adding } \\
\text { amount } \\
(\%) \\
\end{array}$ & $\begin{array}{l}\text { Height } \\
(\mathrm{mm})\end{array}$ & $\begin{array}{l}\text { Air } \\
\text { weight } \\
(\mathrm{g}) \\
\end{array}$ & $\begin{array}{c}\text { Water } \\
\text { weight } \\
(\mathrm{g}) \\
\end{array}$ & $\begin{array}{c}\text { Dry } \\
\text { weight } \\
(\mathrm{g})\end{array}$ & $\begin{array}{c}\text { Bulk } \\
\text { density } \\
\left(\mathrm{g} / \mathrm{cm}^{3}\right) \\
\end{array}$ & $\begin{array}{c}\text { Splitting } \\
\text { load }(\mathrm{kN})\end{array}$ & $\begin{array}{l}\text { Flow } \\
\text { value } \\
(\mathrm{mm}) \\
\end{array}$ & $\begin{array}{l}\text { Strength before } \\
\text { freeze-thaw } \\
(\mathrm{MPa})\end{array}$ & $\begin{array}{c}\text { Strength after } \\
\text { freeze-thaw } \\
(\mathrm{MPa})\end{array}$ & $\begin{array}{l}\text { Strength } \\
\text { ratio }(\%)\end{array}$ \\
\hline \multirow{8}{*}{4} & 63.1 & 1292.9 & 795 & 1293.9 & 2.592 & 11.93 & 1.8 & 1.189 & I & \multirow{9}{*}{$98.02 \%$} \\
\hline & 63 & 1288.8 & 795.1 & 1289.8 & 2.605 & 12.2 & 2.38 & I & 1.217 & \\
\hline & 63 & 1291.3 & 793.6 & 1292.4 & 2.589 & 14.17 & 2.85 & 1.414 & I & \\
\hline & 62.5 & 1289.7 & 793.2 & 1290.5 & 2.593 & 13.31 & 2.25 & / & 1.339 & \\
\hline & 63.5 & 1292.5 & 792 & 1293.5 & 2.577 & 12.06 & 2.3 & 1.194 & 1 & \\
\hline & 63.5 & 1291.7 & 795.2 & 1293 & 2.595 & 12.44 & 2.09 & 1 & 1.232 & \\
\hline & 63.2 & 1290.6 & 793.7 & 1292.2 & 2.589 & 13.33 & 1.96 & 1.326 & / & \\
\hline & 63.4 & 1291.8 & 788 & 1293.4 & 2.556 & 12.44 & 2.1 & 1 & 1.234 & \\
\hline Average & 63.2 & 1291.2 & 793.2 & 1292.3 & 2.587 & I & 1 & 1.281 & 1.255 & \\
\hline
\end{tabular}

Table 4. AC-13 with $6 \%$ modifier freeze-thaw splitting strength test.

\begin{tabular}{|c|c|c|c|c|c|c|c|c|c|c|}
\hline $\begin{array}{c}\text { Adding } \\
\text { amount } \\
(\%)\end{array}$ & $\begin{array}{c}\text { Height } \\
(\mathrm{mm})\end{array}$ & $\begin{array}{c}\text { Air } \\
\text { weight } \\
(\mathrm{g})\end{array}$ & $\begin{array}{c}\text { Water } \\
\text { weight } \\
(\mathrm{g})\end{array}$ & $\begin{array}{c}\text { Dry } \\
\text { weight } \\
(\mathrm{g})\end{array}$ & $\begin{array}{c}\text { Bulk } \\
\text { density } \\
\left(\mathrm{g} / \mathrm{cm}^{3}\right)\end{array}$ & $\begin{array}{c}\text { Splitting } \\
\text { load }(\mathrm{kN})\end{array}$ & $\begin{array}{c}\text { Flow } \\
\text { value } \\
(\mathrm{mm})\end{array}$ & $\begin{array}{c}\text { Strength before } \\
\text { freeze-thaw } \\
(\mathrm{MPa})\end{array}$ & $\begin{array}{c}\text { Strength after } \\
\text { freeze-thaw } \\
(\mathrm{MPa})\end{array}$ & $\begin{array}{c}\text { Strength } \\
\text { ratio }(\%)\end{array}$ \\
\hline & 64.2 & 1295.6 & 796.3 & 1297.8 & 2.583 & 12.49 & 2.21 & 0 & 1.283 \\
\cline { 2 - 11 } & 63.2 & 1291.9 & 795.4 & 1292.9 & 2.597 & 15.95 & 2.23 & 1.487 & 0 \\
\cline { 2 - 11 } & 63.3 & 1292.6 & 796 & 1293.7 & 2.597 & 14.91 & 2.34 & 0 & 1.481 \\
\cline { 2 - 11 } & 63.1 & 1293.4 & 795.3 & 1294.2 & 2.593 & 17.00 & 1.96 & 1.494 & 0 \\
\cline { 2 - 11 } & 64.5 & 1295.3 & 792.6 & 1297.3 & 2.566 & 14.58 & 1.71 & 0 & 1.421 \\
\cline { 2 - 11 } & 62.7 & 1290.3 & 791.8 & 1291.5 & 2.582 & 16.91 & 1.72 & 1.496 & 0 \\
\cline { 2 - 10 } & 62.8 & 1294 & 794.2 & 1295.3 & 2.582 & 15.69 & 2.05 & 0 & 1.571 \\
\hline \multirow{2}{*}{ Average } & 63.5 & 1289.3 & 792.4 & 1290.7 & 2.587 & 19.19 & 1.81 & 1.5 & 0 \\
\hline
\end{tabular}

Table 5. Immersion test result of the anti-icing asphalt mixture specimen.

\begin{tabular}{|c|c|c|c|c|c|c|c|c|c|c|}
\hline \multirow{2}{*}{ Sample } & \multicolumn{10}{|c|}{$\mathrm{Cl}^{-}$concentration $\left(10^{-2} \mathrm{~mol} / \mathrm{L}\right)$} \\
\cline { 2 - 24 } & 1 & 2 & 3 & 4 & 5 & 6 & 7 & 8 & 9 & 10 \\
\hline A & 0.05 & 0.15 & 0.27 & 0.28 & 0.28 & 0.29 & 0.29 & 0.29 & 0.29 & 0.29 \\
\hline B & 0.04 & 0.13 & 0.25 & 0.26 & 0.27 & 0.27 & 0.28 & 0.28 & 0.28 & 0.28 \\
\hline
\end{tabular}

A continuation of the above table

\begin{tabular}{|c|c|c|c|c|c|c|c|c|c|c|}
\hline \multirow{2}{*}{ Sample } & \multicolumn{10}{|c|}{$\mathrm{Cl}^{-}$concentration $\left(10^{-2} \mathrm{~mol} / \mathrm{L}\right)$} \\
\cline { 2 - 12 } & 11 & 12 & 13 & 14 & 15 & 16 & 17 & 18 & 19 & 20 \\
\hline A & 0.29 & 0.29 & 0.29 & 0.29 & 0.29 & 0.29 & 0.29 & 0.29 & 0.29 & 0.29 \\
\hline B & 0.28 & 0.28 & 0.28 & 0.28 & 0.28 & 0.29 & 0.29 & 0.29 & 0.29 & 0.29 \\
\hline
\end{tabular}


ICMEE 2015

Table 6. Shower test on the anti-icing asphalt mixture rutting specimen.

\begin{tabular}{|c|c|c|c|c|c|c|}
\hline \multirow{2}{*}{$\begin{array}{l}\mathrm{Cl}^{-} \text {concentration } \\
\text { Shol/L) }\end{array}$} & \multicolumn{7}{|c|}{ Test temperature } \\
\cline { 2 - 7 } & $-10^{\circ} \mathrm{C}$ & $0{ }^{\circ} \mathrm{C}$ & $5^{\circ} \mathrm{C}$ & $15^{\circ} \mathrm{C}$ & $25^{\circ} \mathrm{C}$ & $35^{\circ} \mathrm{C}$ \\
\hline 1 & 0.00099 & 0.00076 & 0.00109 & 0.00085 & 0.00075 & 0.00086 \\
\hline 2 & 0.00107 & 0.00083 & 0.00088 & 0.00085 & 0.00084 & 0.00082 \\
\hline 3 & 0.00118 & 0.00086 & 0.00092 & 0.00087 & 0.00088 & 0.00084 \\
\hline 4 & 0.00130 & 0.00085 & 0.00097 & 0.00104 & 0.00093 & 0.00090 \\
\hline 5 & 0.00130 & 0.00087 & 0.00097 & 0.00108 & 0.00097 & 0.00092 \\
\hline 6 & 0.00139 & 0.00090 & 0.00095 & 0.00106 & 0.00093 & 0.00092 \\
\hline 7 & 0.00138 & 0.00094 & 0.00098 & 0.00106 & 0.00098 & 0.00098 \\
\hline 8 & 0.00139 & 0.00098 & 0.00099 & 0.00112 & 0.00099 & 0.00096 \\
\hline 9 & 0.00144 & 0.00096 & 0.00100 & 0.00121 & 0.00099 & 0.00101 \\
\hline 10 & 0.00149 & 0.00097 & 0.00102 & 0.00116 & 0.00098 & 0.00097 \\
\hline Total & 0.01294 & 0.00895 & 0.00982 & 0.01027 & 0.00930 & 0.00922 \\
\hline
\end{tabular}

Table 7. Residual analysis of the anti-icing modifier.

\begin{tabular}{|c|c|c|c|c|c|c|}
\hline Temperature & $-10^{\circ} \mathrm{C}$ & $0{ }^{\circ} \mathrm{C}$ & $5{ }^{\circ} \mathrm{C}$ & $15^{\circ} \mathrm{C}$ & $25^{\circ} \mathrm{C}$ & $35^{\circ} \mathrm{C}$ \\
\hline $\mathrm{Cl}^{-}$loss amount (mol/L) & 0.01294 & 0.00895 & 0.00982 & 0.01027 & 0.00930 & 0.00922 \\
\hline Modifier loss amount (g/L) & 0.45951 & 0.31784 & 0.34875 & 0.36474 & 0.33002 & 0.32738 \\
\hline $\begin{array}{c}\text { Modifier loss mass after shower } \\
\text { of 72L water (g) }\end{array}$ & 33.08438 & 22.88472 & 25.10966 & 26.26108 & 23.76107 & 23.57119 \\
\hline Modifier residual mass (g) & 491.9156 & 502.1152 & 499.8904 & 498.739 & 501.239 & 501.4289 \\
\hline $\begin{array}{c}\text { Ratio of the modifier residual } \\
\text { mass vs specimen total mass (\%) }\end{array}$ & $4.69 \%$ & $4.78 \%$ & $4.76 \%$ & $4.75 \%$ & $4.77 \%$ & $4.77 \%$ \\
\hline $\begin{array}{c}\text { Ratio of the modifier loss mass } \\
\text { vs specimen total mass (\%) }\end{array}$ & $0.31 \%$ & $0.22 \%$ & $0.24 \%$ & $0.25 \%$ & $0.23 \%$ & $0.23 \%$ \\
\hline $\begin{array}{c}\text { Prediction of the modifier's } \\
\text { working years }\end{array}$ & 14.2 & 20.8 & 19.1 & 18.3 & 19.9 & 19.9 \\
\hline
\end{tabular}




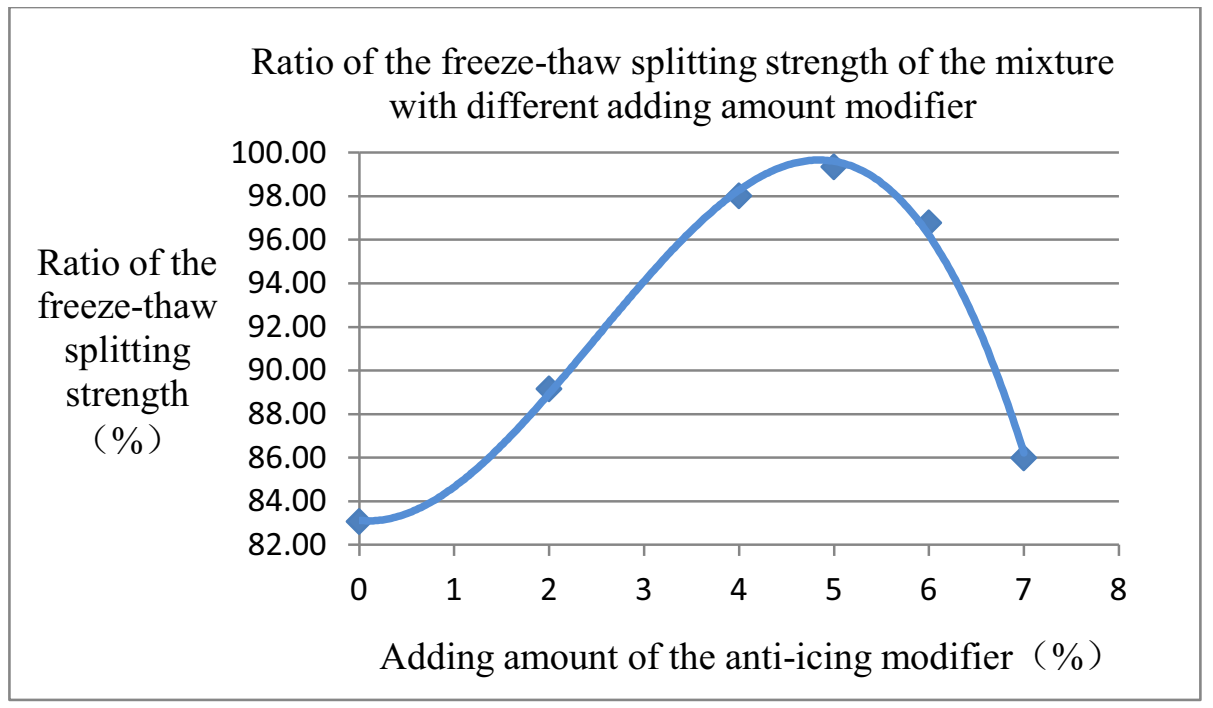

Figure 1. Ratio of the freeze-thaw splitting strength of the asphalt mixture with different adding amount modifier.

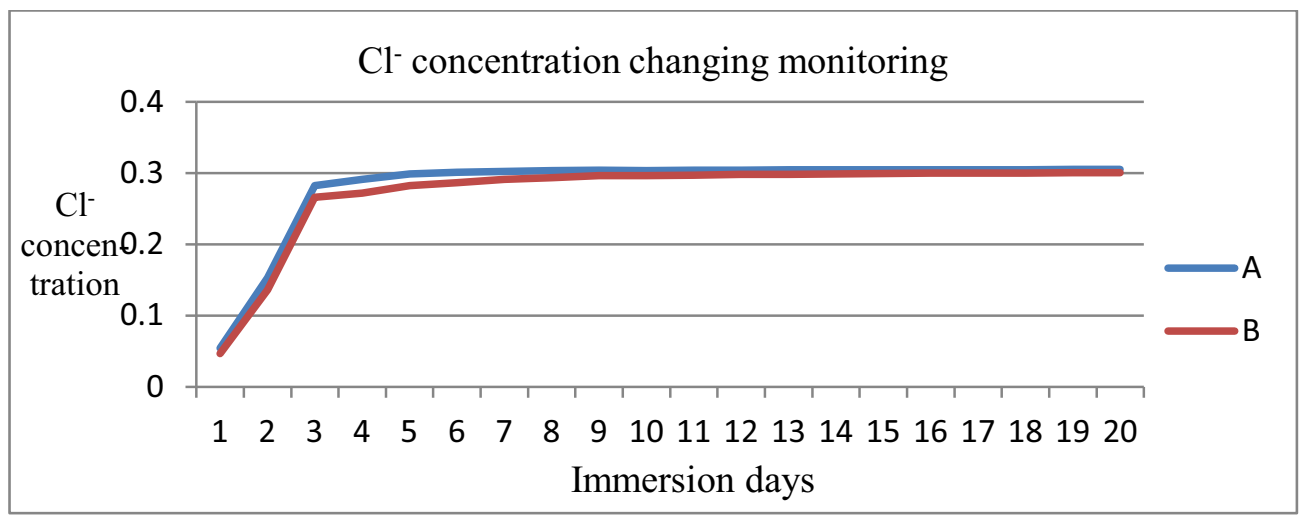

Figure 2. Precipitation of the chloride ion.

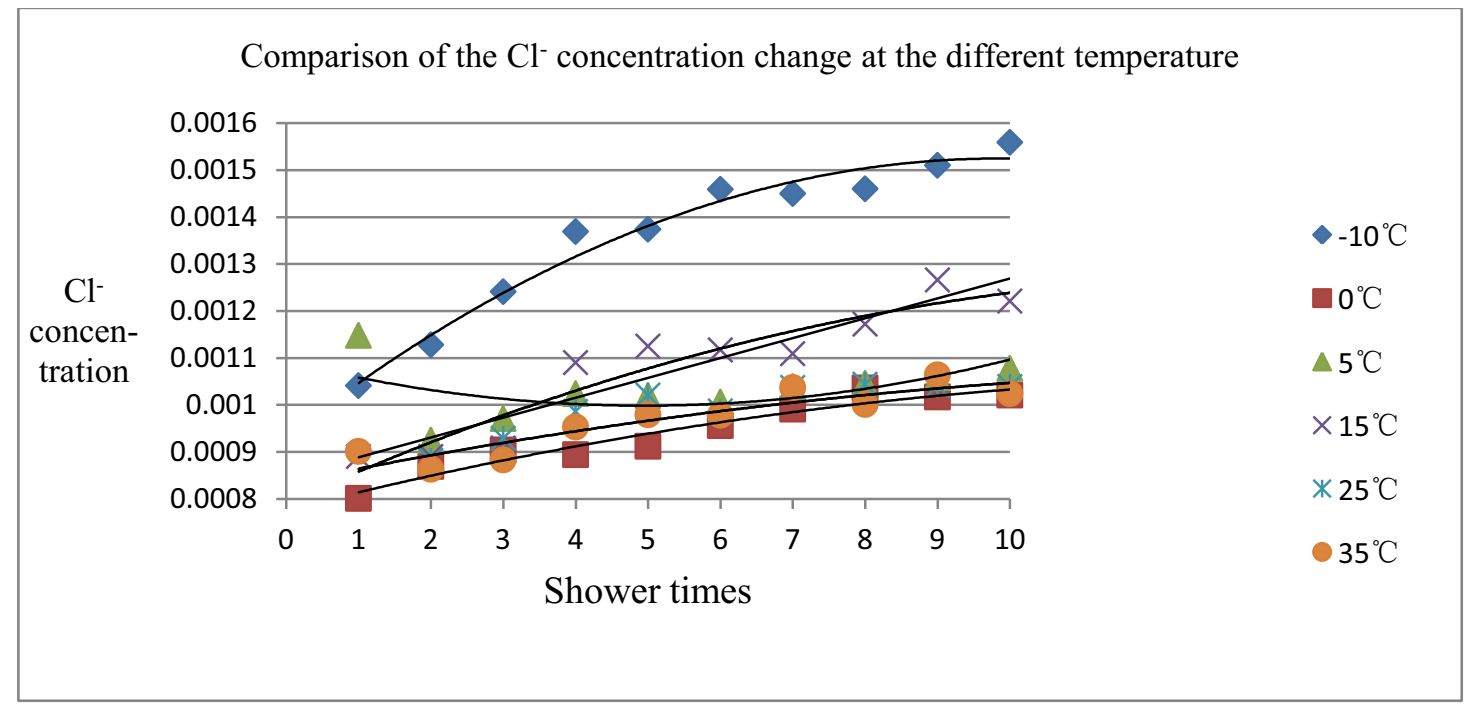

Figure 3. Shower test on the specimens at the different temperature. 


\section{References}

1. H.Y. Liu, P.W. Hao, "Technology and Development Trend of Pavement Deicing", Road Machinery \& Construction Mechanization, 18-21 (11/2008)

2. G. Cheng, S.J. Du, M.J. Zhang, "The Study on Road Snow Additives", Shanxi Science \& Technology of Communications, 178 (1/2006)

3. L.T. Cao, S. Liu, Y.F. Han, "Analysis on Key Technology and Development Trend of De-icing and Anti-icing" The world of Building Materials, 53-56 (5/2010)

4. L.H. Song, Z.L. Jin, A.S. Liu, "The Development of Efficient Corrosion Inhibitor for Environmentfriendly Snowmelt Additives", Journal of Salt and Chemical Industry, 8 (2012)

5. B.C. Zhang, S.M. Liu, "Winter Road Snow Removal Methods Discussed", Shandong Science \& Technology, 76 77 (1/2004)

6. F. Wang, S. Han, H.W. Zhang, O.M. Xu, "A Study on Application of Salt Anti-freezing Asphalt Mixture", Highway, 176-179 (3/2009)

7. J. Tang, "A Brief Talk on Anti-icing and De-icing Measures of Road in Winter [C]".13th REAAA Conference .3rd ROTREX Organizing Committee, $1 \sim 6$ (2009)

8. F. Li, Z. Wang, "Experiment on Road Performance of Asphalt Mixture with Automatic Long-term Snowmelt Agent", Journal of Highway and Transportation Research and Development, Vol. 6, No. 4, pp. 11-17 (2012) 